\title{
City-Region: A Way Forward to China's Urbanisation?
}

\section{-A Regional Perspective}

\author{
Yang Jian \\ School of Public Administration and Law \\ Southwest Jiaotong University \\ Chengdu, China \\ (120747576@qq.com)
}

\author{
Wang Min \\ School of Public Administration and Law \\ Southwest Jiaotong University \\ Chengdu, China \\ (352638504@qq.com)
}

\begin{abstract}
The paper aims at researching if city-region is a way forward to China's Urbanisation, mainly from the regional perspective through the analysis of the connotation of city-region. The paper point out it's important that policy making for development purposes at the city-region level.
\end{abstract}

Keywords—city-region; urbanisation; regional economy; China

\section{INTRODUCTION}

With the advent of globalisation and economic restructuring In the late $1990 \mathrm{~s}$, regional and city scales have changed. A great deal of attention has been paid in the academic literature to the growing weight of sub-national arrangements1. City-region is one of framework.

It's also the period of rapid urbanization for China that the last two decades. Nowadays China passed the US to become the country with the largest number of urban residents in the world. Despite a long political and cultural bias against urbanization, marketoriented reforms since 1978 have created conditions that will transform China into a predominantly urban nation early in the next decades.

The China government is always seeking a more systematic approach to urban development. The approach should balance economy and environment, fairness and efficiency. As well it should strengthen agglomeration economies that can generate a wide range of employment opportunities for rural migrants.

The paper aims at researching if city-region is a way forward to China's Urbanisation, mainly from the regional perspective.

\section{LITERATURE REVIEW}

The concept of the City-Region has a long history. It has been the basis for a wide variety of academic studies, not least

\footnotetext{
${ }^{1}$ Swyngedouw, E. (1997) . 'Neither global nor local:

"glocalization" and the politics of scale', in K. Cox (ed.), Spaces of globalization, New York: Guildford, pp.138-66;

Brenner, N. (1999) . 'Globalization as reterritorialisation: the rescaling of urban governance in the European Union', Urban Studies, $36,431-51$
}

in the central place theories of Christaller and Losch who saw hierarchical sets of cities nesting within each other and serving populations drawn from within regular hexagonal catchment areas at successively larger scales. More applied policyrelevant studies in England date from the early work of Smailes and Green in the 1940s and '50s and Senior (whose minority report on administrative boundaries in the $1960 \mathrm{~s}$ argued for a City-Region approach) 2 .

( Robson, Barr et al. 2006 ) City-Regions essentially comprise a central urban core together with the relevant commuter hinterland. Their conceptual underpinning is clear: City-Regions are essentially functional definitions of the economic but also of the social 'reach' of cities. The aim in defining them is therefore to identify the boundaries of those areas in which a majority of the population see the core city as 'their' place - in which they may work, shop for certain types of goods, visit for entertainment and leisure pursuits, and with which they identify. As with any such geometry, there is bound to be fuzziness and overlap at the boundaries of many City-Regions; and the degree of self-containment is likely to vary for different kinds of activity - whether for commuting to work, shopping, leisure, or whatever.

Although successive reorganisations of local government in the last half-century have never embodied the geometry of City-Regions, the argument for their relevance as administrative or strategic entities has grown ever more powerful. The increased range of commuting brought about by greater car ownership and higher employment mobility has widened the functional area of English cities, as a result

\footnotetext{
${ }^{2}$ Smailes, A.E. (1947) 'The analysis and delimitation of urban

fields', Geography, 32;

Green, F.H.W. (1950) 'Urban hinterlands in England and

Wales', Geographical Journal, 116;

Christaller, W. (1933) Die centralen orbe in Suddeutschland, Jena;

Losch, A. (1954) The economics of location, New Haven.

For a summary see, for example, Berry, B.J.L. (1967)

Geography of market centers and retail distribution, Prentice-Hall.
} 
making existing local authority district boundaries increasingly less representative of the real functional reach of towns and cities. Increasingly, the scale of governance decision-making and policy implementation in fields such as transport, housing and physical infrastructure investment have become divorced from the real functional areas of towns and cities. Realigning the two may be a powerful means of improving the efficiency of strategic planning for sub-regional areas, with consequent improvements in outcomes for all parts of the country.

The impulse for discussions about regional and subregional reform, and the apparently growing momentum for greater regional autonomy in the late 1990s, can be seen within the context of the extensive debate about the 're-scaling' of institutional arrangements for governance, and economic activity, as a response to the challenges posed by economic globalisation. Briefly, the argument is that the advent of globalisation and the associated economic restructuring have eroded the power and scope of nation-states and has led to a reinvigoration of sub-national institutional arrangements operating at the regional and city scales. Together with the concomitant growth in powers assumed by supra-national bodies such as the EU, this has led to a 'hollowing out' of the nationstate, and a new and shifting relationship between institutions up and down the localglobal hierarchy. A great deal of attention has been paid in the academic literature to the growing weight of sub-national arrangements3. Indeed, Scott posits a constellation of global City-Regions - defined as cosmopolitan metropolises and their wider regions - as the spatial foundations of the world economy.

The closest current formal spatial definition of the CityRegion is that based on travel-towork-areas (TTWAs), which are relatively self-contained internally-contiguous labour markets. TTWAs were the outcome of interest, from the late 1970s, in using the concept of the Local Labour Market Area

( LLMA ) to represent sub-regional functional areas. A central aim was that any spatial unit for research and policymaking should reflect the relationship between labour supply and demand within a local area: Thus the LLMA should ideally not only represent areas within which identifiable processes of labour matching were taking place, but often also tend to approximate other related localized economic subsystems such as local housing markets and shopping centre hinterlands. As a

' locality', then, the LLMA offers the great advantage of representing a spatially-defined 'community of interest' .4

Much of the methodological approach to the definition of City-Regions was based on research from Newcastle' s Centre

\footnotetext{
${ }^{3}$ Swyngedouw, E. (1997) . 'Neither global nor local:

"glocalization" and the politics of scale', in K. Cox (ed. ), Spaces

of globalization, New York: Guildford, pp.138-66;

Brenner, N. (1999) . 'Globalization as reterritorialisation: the rescaling of urban governance in the European Union', Urban Studies, $36,431-51$.

${ }^{4}$ Coombes, M.G. Green, A.E. and Owen, D.W. (1988)

"Substantive issues in the definition of 'localities': evidence from sub-group Local Labour Market Areas in the West Midlands" Regional Studies, 22, 304.
}

for Urban and Regional Development Studies (CURDS) in the early 1980s. Their attempt to define cities as self-contained functional entities resulted in a framework of 228 urban centres and the allocation of the whole of Britain between each of these centres as their 'functional regions' . Recognising that the functional regions themselves produced under-bounded definitions of the metropolitan areas, they proposed twenty

'city-regions' by aggregating functional regions that were closely linked to each other by commuting flows5.

\section{Connotation of City-Regions}

As noted above, travel-to-work is only one of a range of possible definitions of the City-Region concept. Since the linkages between cores and hinterlands vary in terms of different functions, (Robson, Barr et al. 2006) explores five different approaches to the definition of City-Regions:

\section{A. Labour-market definitions}

The most commonly used approach is to focus on labour markets, as measured by journey-to-work.

\section{B. Housing-market definitions}

City-Regions can also be defined as those areas in which households search for residential locations. This implies that house prices within such areas would move roughly in tandem. In theory, there is a close relationship between labour-market and housing-market areas since both are in principle strongly determined by commuting flows ( at least for those households that are economically active ). In practice, however, the search areas used by households making residential location decisions tend to be strongly influenced by their 'mental maps' of areas with which they are familiar. Residential moves within a labour market area consequently tend to be restricted to relatively short distances. Housingmarket areas are therefore generally smaller than labour-market areas; for example, they frequently differentiate between sectors radiating out from core urban areas, so that house prices and the balance of supply and demand may be differentiated within wider labour-market areas.

\section{Economic activity-based definitions}

While access to labour markets is a key element of business performance, other aspects of the City-Region may be highly significant for economic competitiveness. The richness of the surrounding area in terms of potential links other businesses and business services may be important in terms of the supply chains and procurement activities of firms. In principle this would seem to be an element of growing importance as cityregion-based activities come to play an ever more significant role in economic activity. It may also be that some aspects on the demand side are also relevant to the functioning of CityRegions. However, the difficulty in exploring either the supply or demand side is that there is a dearth of relevant data.

\section{Service-district definitions}

Service areas demarcate those regions from which users of city-based goods and services are drawn. Central place theory

\footnotetext{
${ }^{5}$ Champion et al, (1983 ) 'A new definition of cities', Town and Country Planning, 52, 305-7.
} 
postulated an elegant model of settlements in which customers use their nearest available service so that a large number of places offer a restricted array of frequently-used services and are nested within progressively smaller numbers of 'higherorder' settlements which offer increasingly wide arrays of more specialised services. While the geometrical patterns of central place theory have little potency today - given changes in service provision and increased mobility - the underlying principle of frequency of use and distance travelled still has some potency.

City-Regions based on higher-level services can therefore be defined in terms of the use of services such as major hospitals, theatres and concert halls, major shopping centres, international airports and the like.

\section{E. Administrative definitions}

Administrative regions can be considered a subset of service districts. While their boundaries are formal and 'artificial' they are functional areas in so far as services and strategies are developed within the defined boundaries. Some of the administrative areas are formal - for example, the structures of local authorities, agencies such as police, health authorities, learning and skills councils and the like, quangos, etc. - some are informal and based on non-statutory partnerships.

\section{CONCLUSION}

Hence, policy making for development purposes at the cityregion level-while likely to prove a useful approach - may need to be complemented with additional policies in order to maximize the advantages of better-targeted policies, enhanced policy innovation, and greater empowerment and improved governance, while minimizing the risks of inadequate financing, debt, lack of economies of scale and scope, capacity constraints and zero-sum territorial competition. Otherwise, the promotion of city-region approaches to development policy may simply become a recipe for greater inequality and for an even greater influence of elites on policy making at the local level.

\section{ACKNOWLEDGMENT}

I would like to express my gratitude to all those who have helped me during the writing of this thesis. I gratefully acknowledge the help of my supervisor Professor Dai Bing. I do appreciate his patience, encouragement, and professional instructions during my thesis writing.

\section{REFERENCES}

[1] Ahn, C. H. (2003). The Evaluation of Korean New Towns: A study with comparison with British new towns. Birmingham Birmingham University. Ph.D.

[2] Carrillo, F. J. (2004). "Capital Cities: a taxonomy of capital accounts for city-region cities." Journal of City-region Management 8(5): 28-46.

[3] Cohen, B. (2004). "Urban Growth in Developing Countries: A review of current trends and a caution regarding existing focecasts." World Development 32(1): 23-51.

[4] Healey, P. (2002). "On Creating the 'City' as a Collective Resource." Urban Studies 39(10): 1777-1792.

[5] Robson, B., R. Barr, et al. (2006). A framework for city-regions working paper 1 mapping city-regions Newcastle Centre for Urban and Regional Development Studies

[6] Yin, R. K. (1994). Case study research : design and methods. Thousand Oaks, Calif. ; London, Sage Publications.

[7] Yin, R. K. (2003). Case study research : design and methods. Thousand Oaks, Calif. ; London, Sage Publications. 